\title{
SOCIAL CONTEXTS AND CONVERSATIONAL IMPLICATURESIN CONVERSATIONS AMONG FAMILY MEMBERS
}

\author{
Aldha Williyan \\ Universitas Negeri Semarang \\ alwilliyan@gmail.com
}

\begin{abstract}
Social contexts play important roles in the conversations. The speakers need to always refer to those contexts when conversing. Moreover, conversations do not only contain literal meanings but also meanings beyond the utterances. This study therefore aims to reveal the social contexts that influence how the participants talk and produce conversational implicatures in the conversations,particularly among family members. Four participants are involved with this study. They are a father, mother, son and daughter from one family. The data are taken from the conversations that occur only before school and father's work using recording and note taking. This study shows that the conversation among those four participants is rich of conversational implicatures. There are several types of conversational implicatures found in this study. Those are standard implicature with the highest emergence, particularized conversational implicature, generalized conversational implicature, and a deliberate flouting of the maxims. This study concludes that the use of conversational implicature is strongly influenced by the social contexts of the participants, such as age, power or social status and social distance.
\end{abstract}

Keywords: conversational implicature, conversational maxims, social contexts

\section{BACKGROUND}

According to Wardhaugh $(2010,118)$ sociolinguistics is defined as "the study of language use within or among groups of speakers". Itfocuses on revealing why the participants in the conversations talk variously in various social contexts (Holmes, 2013). This present study which is also sociolinguistics research no wonder aims to investigate the social contexts in the conversation among family members, particularly when they produce conversational implicature. To determine thesocial contexts, there are at least three elements that need to be considered. The first is social distance defined by Holmes (2013, $240)$ as the relationships among the participants in the conversations. Holmes $(2013,289)$ adds relative age as the second element that influences the way people use the language. Then, the third is power defined by Holmes \& Stubbe (2003) as "a relative concept which includes both the ability to control others and the ability to accomplish one's goals".

Furthermore, cconversation, particularly among family members, is not as simple as what it looks. It contains speakers' meaning or an illocutionary (Paltridge, 2000: 39). This circumstance strengthens the fact that, in certain moments, speakers utter something with certain hidden meaning behind it (Thomas, 1995: 56). In this case, context is essential (Yule, 2003: 35). Without it, the people cannot participate in the 
communication process (Mey, 1993: 39). Context also influences the meaning of the utterances, as Thomas (1995) states that context determines whether the utterances contain meaning level I which deals with utterance meaning or level II which deals with the communicative intention of the speakers. Meaning, particularly meaning level II, is the center of a term called conversational implicature as it relates to the meaning beyond the words. (Thomas, 1995: 57).It means using implicature is illustrated as drawing conclusion of the utterances produced by the speakers which intend to say something indirectly in certain context.

Preceding explanation has presented the importance of context as the main factor which influences the conversational implicature in communication. Mey $(1993,39)$ defines context as "the universe of everyday language". Conversational implicature no wonder often occurs in daily conversation of the people, including family members. That is why, in pragmatics, conversational implicature is one of the most essential terms (Levinson, 1983: 97). Therefore, it is not difficult to search researches concerning on it.Several examples are The work of Nanda, Sukyadi, and Sudarsono (2012) entitled "Conversational Implicature of the Presenters in Take Me Out Indonesia", the work of Fang \& Xin (2017) entitled "An Analysis of Conversational Implicature in Nirvana in Fire from the Perspective of Cooperative Principle", the work of Michael \& Muthusamy (2015) entitled "Conversational Implicature and Cooperativeness in D.H Lawrence's Sons and Lovers", the work of Widiana (2014) entitled "A Pragmatics Study on Jokes and the Implicature in Broadcast Messages", and the work of Jingjie (2016) entitled "A Study on the Conversational Implicature in Sons and Lovers From thePerspective of Cooperative Principle".

In "Conversational Implicature of the Presenters in Take Me Out Indonesia", Nanda, Sukyadi, and Sudarsono (2012) investigate conversational implicature that the presenters of Take Me Out Indonesia, a popular game shows in Indonesian television,operate within their utterances along with the possible implications that lie behind the implicature. This qualitative study reveals that the presenters tends to use generalized conversational implicature rather than the particularized. Those findings concludes that various types of implicature were used in informal game show conversation to make interaction flows smoothly. Similarly, in "An Analysis of Conversational Implicature in Nirvana in Fire from the Perspective of Cooperative Principle",Fang \& Xin (2017) use the theory of Cooperative Principle and implicature to analyze the dialogue in Nirvana in Fire, Chinese TV series. Through this study, it is found that the characters in the fiction try to convey their implied meaning by violating the maxims of the Cooperative Principle. It indicates that the Cooperative Principle plays an indispensable role in analyzing the TV plays Nirvana in Fire. Lastly, this study also shows the character's implied intention and helps the audience better understand the plot.

In "Conversational Implicature and Cooperativeness in D.H Lawrence's Sons and Lovers", Michael \& Muthusamy (2015)examines the conversational implicature and the use of cooperative principles in the novel Sons and Lovers (1913) by D.H. Lawrence (Lawrence). The purpose of this study is to identify the types of conversational implicature and the cooperative principles used in various relationships in the text and the reason behind its use during the industrialisation era in the novel. The selected utterances from the novel are analysed using Gricean cooperative maxims which are then related to the social norms during the industrialised era in the novel. The findings show that the success of a conversation depends upon the various speakers' approach to the interaction. In the novel, conversational implicature among the characters gives immense meaning with virtually little actual speech. Then, Jingjie (2016) conducts similar researchentitled "A 
Study on the Conversational Implicature in Sons and Lovers From thePerspective of Cooperative Principle".This paper mainly analyzes the conversation between Paul and his parents using the Cooperative Principle.

Differently, Widiana (2014) attempts to deal with jokes by doing the study entitled "A Pragmatics Study on Jokes and the Implicature in Broadcast Messages". The research applies the pragmatic equivalent method to analyze the topics of jokes based on the implicatures contained in them. Furthermore, the method is also applied to reveal the purpose of creating implicature in jokes. The findings include the kinds of implicature found in jokes which are classified into conventional implicature and conversational implicature. Then, in detailed analysis, implicature in jokes is divided into implicature related to gender, culture, and social phenomena. Through this study, the conclusion is made that implicature in jokes may not only be used to give entertainment but also to soften criticisms or satire so that it does not sound rude and harsh

The examples above are only five from thousand researches dealing with social contexts and conversational implicature. However, the research focusing on investigating conversational implicature among family members has received less attention. That fact therefore becomes the main reason to conduct this present study in order to reveal the new findings which are important for the development of the knowledge in the aspect of conversational implicature.To begin doing that research, the differences between conventional and conversational implicature have to be explained as implicature is divided into those two.

Context is the one that distinguishes both implicatures. In conventional implicature, context does not really influence the meaning of the utterances. The sense of the conventional implicature always carries the same meaning, regardless of the context where it occurs (Thomas, 1995: 57). Thomas $(1995,57)$ provides an example of it. It is when someone says she was cursed with a stammer, unmarried but far from stupid. The previous example shows that conventional implicature is represented by but which wants to make a point about contrast. Whatever the context is, the word butcarries the implicature that what follows will run counter to expectations. This is what makes conventional implicature different with conversational implicature.

In conversational implicature, context plays a very crucial role as the intended meaning of the speakers is influenced by it. The example is when a girl says I have so many homeworks to a boy who asks her to have dinner together. The intention of the girl is not giving information but she has meaning beyond her utterance, namely to refuse the invitation from the boy. Hence, conversational implicature arises only in a particular context of utterance (Thomas 1995: 58). To understand the meaning of the speakers' utterances, the listeners generally are faced with two circumstances. They sometimes need context so much to get the real meaning of certain utterances, but there is a time when they are able to get the meaning without noticing the context that much. It is because there are two types of conversational implicature proposed by Yule (2003, see also Paltridge, 2000: 45). Those are generalised conversational implicature which is not strong context-bounded and particularised conversational implicature which is strong context-bounded.

Furthermore, conversational implicature deals with cooperative principles which consist of four maxims. Speakers shows that they want to cooperate by focusing on those four maxims. They speak truely to follow maxim of quality, briefly to follow maxim of quantity, relevantly to follow maxim of relation, and clearly to follow maxim of manner (Cruse, 2000). However, they often intentionally do not follow those four maxims. This is 
what triggers the conversational implicature. Cruse $(2000,358)$ also points out two possibilities of how implicatures arise. It can be standard implicatures which deals with speakers following the four maxims and a deliberate flouting of the maxims which deals with speakers who do not follow the maxims.

Cutting (2002) presents four kinds of flouting the maxims namely flouting quantity, quality, relation and manner. In flouting quantity, she says that the speakers inform the interlocutors too much or too little. Then, in flouting quality, she points out that exaggerating is used by the speakers as in the hyperbole. Meanwhile, in the flouting relation, she argues that the speakers "expect that the hearers will be able to imagine what the utterance did not say, and make the connection between their utterance and preceding one". Lastly, she argues that the speakers in flouting manner emerge to be obscureand often attempt to exclude a third party. Those four flouting maxims are not the final phenomenain the conversation as the speakers are also likely to violate the maxims, infringe the maxims, opt out of the maxims and suspend the maxims.

Thomas (1995) clearly explains those four phenomenon. Firstly, according to her the speakers in violating the maxims intend to mislead the interlocutors by not saying the truth so that they only understand the surface meaning of the utterance. Secondly, in infringing the maxims, the speakers do not have any intention to flout or violate the maxims. They simply are not able to follow the maxims because of some reasons, such as nervousness, drunkenness and excitement. Low ability in using langauge also can be the cause like a young child or foreign learner. Thirdly, in opting out of the maxims, the speakers refrain from the conversation as the sign of unwillingness to cooperate. Lastly, suspending the maxims deals with the fact that "there are occasions when there is no need to opt out of observing the maxims because there are certain events in which there is no expectation on the part of any participant that they will be fulfilled" (Thomas, 1995: 76). The fact that the conversation contains those phenomena leads this present study to conduct the research dealing with social contexts and conversational implicature.

\section{METHOD}

This study investigates the conversational implicature in conversations among family members. The participants in this study are four people from one /family that consists of mother, father, son and daughter. All of them are in home before school and father's work. That is why the data of this study are taken from the conversation among those four participants only before school and the father's work in the morning in only one day. The recording and note taking are used to collect those data. Then, the data are presented in form of paragraphs since it employs qualitative methodology which does not describe the data statistically (Mackey and Gass, 2005: 162). Also, the data are from the actual words or action of the participants (Fraenkel, Wallen, and Hyun, 2012: 427). In analyzing the data, the writers conduct some steps. Firstly, the conversation is transcribed. Secondly, the transcript of conversation is translated into English. Finally, the data are analyzed using the social context and conversational implicature theories presented above and explained deeply in paragraphs.

\section{FINDINGS AND DISCUSSION}

This study, based on the previous explanation, deals with some phenomena related to the conversational implicatures in the conversation among family members before school and father's work. There are some phenomena found by the researcher, such as generalized conversational implicature with only one emergence, particularized conversational implicature with two emergences, standard implicature with nine 
emergences and a deliberate flouting of the maxims with many emergences. In the case of a deliberate flouting of the maxims, there are three emergences of flouting the maxim of relation, one emergence of flouting the maxim of quality, one emergence of flouting the maxim of quantity, two emergences of flouting the maxim of relation \& quantity, one emergence of flouting the maxim of manner, and five emergences of violating the maxim of quality. Below is table 1 that summarizes all those emergences.

Table 1. Conversational Implicatures

\begin{tabular}{|c|c|c|c|}
\hline No. & \multicolumn{2}{|r|}{ Conversational Implicatures } & Emergence \\
\hline 1. & \multicolumn{2}{|c|}{ Generalized conversational implicature } & 1 \\
\hline 2. & \multicolumn{2}{|c|}{ Particularized conversational implicature } & 2 \\
\hline \multirow[t]{3}{*}{3.} & \multicolumn{2}{|c|}{ Standard implicature } & 9 \\
\hline & & Flouting the maxim of relation & 3 \\
\hline & & Flouting the maxim of quality & 1 \\
\hline \multirow[t]{4}{*}{4.} & $\begin{array}{l}\text { A deliberate } \\
\text { flouting }\end{array}$ & $\begin{array}{l}\text { Flouting the maxim of relation } \\
\text { quantity }\end{array}$ & 2 \\
\hline & of the maxims & Flouting the maxim of quantity & 1 \\
\hline & & Flouting the maxim of manner & 1 \\
\hline & & Violating the maxim of quality & 5 \\
\hline
\end{tabular}

The generalized conversational implicature occurs in the conversation between the father and son. The father in this case asks the son about the exam that he will get in that day. Two options are given by the father to the son who has to answer whether two exams are conducted in that day or only one of them. Finally, the son responds briefly by saying only one of the options. Below is the example of the conversation that has been translated into English.

Father: Today, you have math and computer exam, don't you?

Son : Math exam.

The father as the interlocutor of the son does not need to notice the context of the son's utterance as what is said by the son clearly means that today he does not have any computer exam, it is only math exam. The son in this conversation actually implements one of terms related to conversational implicature, namely generalized conversational implicature which is loosely context bounded. The father as the interlocutor no wonder is not required to have any special knowledge in the context to understand the additional meaning of the son's utterance. That simple and short answer from the son indicates that the social distance between the son and father is close. That is why the son does not need to answer with a long utterance to show politeness since they frequently meet so that both of them have understood each other. The son likely will answer the same question differentlywhen the interlocutor is someone with far social distance with him.

Unlike generalized, particularized conversational implicature requires the interlocutors to pay attention on the context of utterances in order to understand the real intention of the speakers. This is like what happen in the conversation between mother and son. The mother utter something which has hidden meaning to the son before he goes to school. Below is the conversation that has been translated into English between both.

Mother: I will pick your sister up. Your bottle of water is on the dining table. 


\section{Son : Ok.}

The example above is one of the two particularized conversational implicatures found in this study. The utterance of the mother has meaning beyond what she says as she does not only inform that the bottle of water is on the table, but she intentionally offers the son to bring the water to his school so that he is not necessary to buy the mineral water again. It is therefore context plays an important role in this case because the hearers depends strongly on it to implicate the utterance correctly. This also indicates that the social distance between both are so close. That is why, even though the mother offers the son that way, it will not hurt the son's feeling as they always meet everyday and have understood each other.

Besides generalized and particularized conversational implicature, another type of implicature that occurs in this study is standard implicature. It is when the speakers follow all the four maxims so that there is no any meaning beyond what is said by the speakers. Below is one of the conversations between the mother and daughter that shows the standard implicature. In the conversation, the mother answer the question of the daughter who are not sure enough about the uniform the daughter needs to wear. The conversation has been translated into English.

Daughter : :Mom, what do I need to wear? I wear Batik today, right? Mother : No, it is "koko" (Kind of Muslimah clothes)

The answer of the mother is clearly the standard implicature as it exactly follows the four maxims. First, it follows the maxim of relation as it is relevant with the question asked by the daughter. Second, it follows the maxim of quality as it contains the truth about the uniform that the daughter needs to wear. A mother surely will not lie in this case. Third, it follows the maxim of quantity as it says what need to be expressed namely about whether or not the daughter wear Batik and informing that koko is the right uniform for the daughter in that day. Finally, it follows the maxim of manner as what is said by the mother is clear and does not trigger confusion. This conversation indicates that the mother knows that producing conversational implicature with something beyond the utterance likely can mislead the daughter to wear the wrong uniform. That is why she decides to produce the standard implicature to ease the daughter to interpret the meaning in order to avoid the daughter fromloosing face by wearing the wrong uniform in the school.

The next explanation is about a deliberate flouting of the maxims. It is when the the four maxims are neglected. In this study, it is found that flouting the maxim of relation is the most frequently used. Below is the translation of one of conversations between father and son in early morning that shows flouting the maxim of relation.

Father : Wake up, wake up, pray Subuh.

Son : What time is it?

The son in this conversation flouts the maxim of relation by replying the father's instruction to wake up irrelevantly. Instead of saying yes as the sign to follow the father's instruction or no to deny the instruction, the son says what time is it? which indirectly means that he needs time to sleep again. The son's response similarly indicates that both of them have close social distance. Therefore, the son is brave enough to reply in that way. He likely will respond differently when who commands him is his teacher, for example, which has far social distance. 
The second most frequent deliberate flouting of the maxims is violating the maxim of quality. It is when the speakers intentionally mislead the hearers. Below is one of examples of violating the maxim of quality that occurs in the conversation between the daughter and mother, exactly after waking up. The conversation has been translated into English.

Daughter : Where is the remote?

Mother : : Missing, take a bath first and I will find it.

The mother actually can follow the maxim of quality by saying the truth of the remote. However, she in this conversation decides to intentionally violate the maxim of quality by not telling the truth even though she actually knows where the remote is. She lies with the purpose to ask the daughter to take a bath because the school time will start soon. It is easy for the mother to produce this violation since she has close social distance with the daughter. Also, the fact that the mother obviously is older and has more power than the daughter eases her to violate the maxims.

Violating the maxim of quality whose purpose is similar with the previous example above occurs in the other two moments. First, it is when the mother lies to the daughter about porridge seller in order the daughter eats more healthy food cooked in the house. Second, it is when the the father lies to the son who takes a bath too long in order the son finish taking a bath and get ready to have breakfast and go to school. Furthermore, there are other two moments when violating the maxim of quality is done for making a joke. Below is one of the examples. It occurs in the conversation between the daughter and father that has been translated into English.

Daughter : The fried rice is bad, who cook this?

Father : : Huuuusss, Mother cooked it. (laughing)

The father responds the daughter by not telling the truth. It is the sign that he intentionally does not follow the maxim of quality to make a joke about who cooks the fried rice. The violation towards the maixm in this conversation is influenced by the social distance of both participants. The father likely will not reply in form of joke when the previous speaker who says that the fried rice is not good has far social distance. The interlocutors will be annoyed instead. Hence, both of them have close social distance.

This study also reveals that there are two moments when the speakers flout two maxims at the same time, namely the maxim of relation and quantity. One of the moment is explained below as the example. It occurs in the conversation between the son and father. Below is the translation of the conversation which has been tranlated into English.

Son : Why it takes so long? What if I am late to go to school?

Father: Tomorrow, wake up at 4, Pray Subuh first. So, you are not in hurry in the morning.

The father in this conversation answers the son's question by intentionally saying irrelevant utterance. Also, his response is more than what is asked by the son. In the other word, the father flouts the maxim of relation and quantity with the purpose to give advice to the son in order to wake up earlier in the next morning. The father's response indicates that he has higher social status or power than the son. The fact that the father is obviously older also strengthens the reason why he can respond by saying that way. In term of the son's utterance, the social distance influences it a lot. The close social distance of the son and father is the reason why they can say the utterances like that.

Previously, it has been explained that the maxim of quantityand relation are flouted at the same time. This study also figures out that maxim of quantity is flouted 
without any other maxims. Below is the example which has been translated into English. It is the conversation between father and son when discussing the price of the book the son needs to buy.

Son : Dad, there is something I need to buy.

Father: How much?

Son : It is around ... I don't know. There is math book, Bahasa Indonesia, and I will go swimming after school.

In this conversation, the answer of the son is more than what the father asks. The son actually can mention the price directly to the father. However, he feels shy because he needs more money than he usually asks to buy these things. Therefore, he does not follow the maxim of quantity in order the father makes his own inference regarding the price. In this case of flouting the maxim of quantity, social status or power plays a big role. The son with lower social status or power shows his respect to his father who has more power by not mentioning the price explicitly. The son knows that he will ask a big favor in form of money to his father. So, flouting the maxim of quantity is used.

As the final findings of this study, there are two other maxims that are flouted. Those are flouting the maxim of quality and manner. The explanation below is started with flouting the maxim of quality that occurs in the conversation between the son and father. In the conversation, the son asks who is in the bathroom and the father responds by saying that it is somebody else instead of him. It indicates that the son needs to infer that indeed it is his father, not somoeone else. Below is the translation of the conversation.

\section{Son : Who is this?}

\section{Father $\quad$ :Mister RT (the lowest administrative division of Indonesia)}

The father clearly does not follow the maxim of quality by not mentioning the truth to let the son making his own inference regarding who is in the bathroom. It shows that the father has more power in this conversation. Lastly, it is the maxim of manner that is flouted. It occurs in the conversation between the daughter and son. Below is the conversation which has been translated into English.

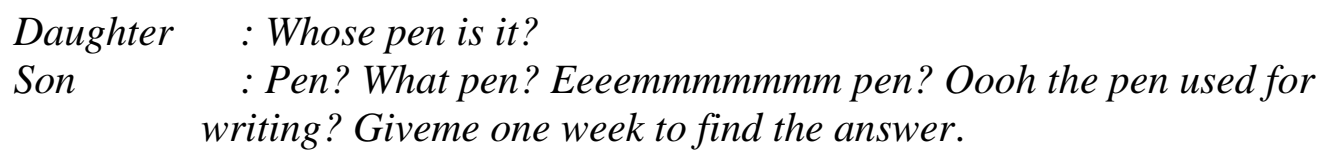

The question asked by the daughter is quite simple. However, the son intentionally makes his response unclear with the purpose to make a joke with his little sister. Being able to make this kind of joke indicates that the son is older than the daughter. It also indicates that they have close social distance. Therefore, this kind of conversation does not cause any bad feeling between the participants.

\section{CONCLUSION}

This study has found that the conversation among family members is rich with a lot of phenomena dealing with conversational implicatures. Even though it only concerns on the conversations in the morning, particularly before school and father's work, there are four types of conversational implicature found in this study. Those are generalized conversational implicature, particularized conversational implicature, standard implicature and a deliberate flouting of the maxims.In terms of generalized conversational implicature, it only appears once. Meanwhile, in terms of particularized conversational implicature, it appears twice in this conversation. Standard implicature in fact appears more than the two previous implicatures with nine emergences. 
Furthermore, in term of deliberate flouting of the maxims, this study finds six phenomena. Those are flouting the maxim of relation with three emergences, flouting the maxim of quality with one emergence, flouting the maxim of relation \& quantitywith two emergences, flouting the maxim of quantity with only one emergence, flouting the maxim of mannerwith only one emergence and violating the maxim of quality with five emergences. Through this present study, it can be concluded that the social context of the participants influences the way they produce the conversational implicature. The social context, such as age, social distance and power or social status, determines how the conversational implicatures are used by the participants.

Lastly, through this study, the writer encourages the other researchers to conduct the other studies dealing with conversational implicature to enrich the findings. First, the fact that this study only deals with the conversation among family members in limited time can be a reason to conduct other studies dealing with this area in a larger scale, such as among people in a certain society. In addition, the future studies also can enter the EFL classroom to deal with the teaching activity to figure out conversational implicature produced by the teachers in teaching certain topic. Not only that, the future researchers are also suggested to connect others pragmatics phenomena with sociolinguistics, particularly the social contexts. It is suggested for them, for instance, to conduct research dealing with how the people employ politeness strategies related to social contexts. There are indeed a lot of gaps that the future researchers can fill to enhance the findings in the area of socilinguistics related to pragmatics.

\section{REFERENCES}

Cruse, D. A. (2000). Meaning in Language. New York: Oxford.

Cutting, J. (2002). Pragmatics and Discourse: A Resource Book for Students. London: Routledge.

Fang, G. Xin, L. (2017). An Analysis of Conversational Implicature in Nirvana in Fire from the Perspective of Cooperative Principle. Journal of Arts \& Humanities, 06 (07): 39-47.

Fraenkel, J. R. and Wallen, N. E. and Hyun, H. H. (2012). How to Design and Evaluate Research in Education. New York: McGraw-Hill

Holmes, J. (2013). An Introduction to Sociolinguistics. Routledge: New York.

Holmes, J.\&Stubbe, M. (2003). Power and Politeness in the Workplace: A Sociolinguistic Analysis of Talk at Work. Routledge: New York.

Jingjie. D. (2016). A Study on the Conversational Implicature in Sons and Lovers From thePerspective of Cooperative Principle. Studies in Literature and Language, 12 (05): 85-90.

Leech, G.N. (1983). Principles of Pragmatics. Essex: Longman

Levinson, S.C. \&Brown. (1987). Politeness: Some Universals in Language Use. New York: CUP.

Levinson, S.C. (1983). Pragmatics. Cambridge: CUP 
Mackey A. and Gass, S. M. (2005). Second Language Research Methodologyand Design. New Jersey: Lawrence Erlbaum Associates, Inc., Publishers

Mey, J. L. (1993). Pragmatics. Oxford: OUP.

Michael, A. S. Muthusamy, C. (2015). Conversational Implicature and Cooperativeness in D.H Lawrence's Sons and Lovers. Journal of Creative Practices in Language Learning and Teaching, 03 (02): 46-61.

Nanda, S. Sukyadi, D. Sudarsono, S. (2012). Conversational Implicature of the Presenters in Take Me Out Indonesia. Indonesian Journal of Applied Linguistics, 01 (02): 120138.

Paltridge, B. (2000). Making Sense of Discourse Analysis. Gerd Stabler: Queensland.

Thomas, J. (1995). Meaning in Interaction. Harlow: Longman.

Wardhaugh, R. (2010). An Introduction to Sociolinguistics. Blackwell Publishers: United Kingdom.

Widiana, Y. (2014). A Pragmatics Study on Jokes and the Implicature in Broadcast Messages. International Journal of Humanities and Social Sciences, 08 (09): 31453148.

Yule, G. (2003). Pragmatics. Oxford: OUP 